\title{
New Expression Method and Characterization of Recombinant Human Granulocyte Colony Stimulating Factor in a Stable Protein Formulation
}

\author{
Ralitza Boubevaa ${ }^{a}$, Christian Reichert ${ }^{a}$, René Handrick ${ }^{b}$, Claudia Müllera, Jürgen Hannemann ${ }^{\mathrm{b}}$, \\ and Gerrit Borchard ${ }^{\star a}$
}

\begin{abstract}
Human recombinant granulocyte colony stimulating factor (rhG-CSF) is widely used in hematology and oncology for the treatment of neutropenia, for the restoration of neutrophil production after bone marrow transplantation, for myelodysplastic syndromes, and aplastic anemia. The $E$. coli expression system is commonly used for fast recombinant production of rhG-CSF at a large scale. We have applied a novel autoinduction method for the batch expression of rhG-CSF to study whether this new system would increase cell mass and targetprotein yield compared to conventional $E$. coli cell culture and induction with isopropyl $\beta$-D-thiogalactopyranoside (IPTG). We could demonstrate 3-fold higher culture densities and a 5-fold higher protein yield compared to IPTG induction without the need to monitor cell growth in a shortened $24 \mathrm{~h}$ expression procedure. rhG-CSF expressed in autoinduction media was successfully extracted from $E$. coli inclusion bodies and refolded by dialysis. After size exclusion chromatography (SEC) purification, rhG-CSF showed similar conformation, biological activity and aggregation profile compared to the commercially available biosimilar TEVAgrastim ${ }^{\circledR}$ (TEVA Pharma AG). Expression by autoinduction is suggested as a cost- and time-effective method for rhG-CSF production.
\end{abstract}

Keywords: Autoinduction media $\cdot$ Protein expression $\cdot$ Protein refolding $\cdot$ Protein stability $\cdot$ rhG-CSF

\section{Introduction}

Colony-stimulating factors are hematopoietic proteins that stimulate the proliferation and differentiation of hematopoietic cells from pluripotent stem cells. Granulocyte colony stimulating factor (G-CSF), in particular, enhances the proliferation of specific myeloid precursor cells into granulocytes. ${ }^{[1]}$ Currently human G-CSF is widely used in hematology and oncology for the treatment of neutropenia, for the restoration of neutrophil production after bone marrow transplantation, for myelodysplastic syndromes, aplastic anemia as well as in the treatment of immunodeficiency and in prevention of infectious complications. ${ }^{[2]}$

\footnotetext{
${ }^{*}$ Correspondence: Prof. G. Borchard ${ }^{a}$

Tel.: +41223796945

Fax: +41223796567

E-mail: Gerrit.Borchard@unige.ch

aSchool of Pharmaceutical Sciences

University of Geneva, University of Lausanne

30 Quai Ernest-Ansermet, $\mathrm{CH}-1211$ Geneva 4

bUniversity of Applied Sciences

35 Hubertus-Liebrecht Straße, D-88400 Biberach,

Germany
}

There are three marketed recombinant forms of human G-CSF (rhG-CSF), which were approved chronologically as filgrastim (Amgen Inc., 1991), lenograstim (Chugai Pharmaceutical Co., 1993) and pegfilgrastim (Amgen Inc., 2007).[3] Among the three, lenograstim is the only version of rhG-CSF produced in a mammalian (Chinese hamster ovary, $\mathrm{CHO}$ ) cell line and presents therefore the glycosylated pattern of the natural human G-CSF. Even though it has been demonstrated that O-glycosylation confers a higher stability to rhG-CSF by protecting the sulfhydryl group of a free Cys 17 residue, it does not influence the biological activity of the therapeutic protein. ${ }^{[4]}$ Thus, the majority of patients are presently treated with filgrastim or its PEGylated version, pegfilgrastim. For both, the protein is recombinantly expressed in Escherichia coli (E. coli) after insertion of the human G-CSF gene into the bacteria and has the same amino acid sequence as human G-CSF plus an $\mathrm{N}$-terminal methionine residue needed for expression. Since the $\approx 19 \mathrm{kDa}$ protein is expressed in bacteria, the typical O-glycosylation obtained in mammalian cells as well as the solubility that the latter confers to G-CSF are lost. The resulting non-soluble rhG-CSF is produced in $E$. $\mathrm{co}$ $l i$ as inclusion bodies (IBs) and needs to be subjected to oxidative refolding in order to restore biological activity of the protein. ${ }^{[5]}$ The refolding of rhG-CSF after expression in E. coli is a crucial step for obtaining filgrastim on a large scale and constant efforts are aiming at improving refolding yields. ${ }^{6]}$ Besides the hurdle of downstream refolding, biosynthesis in E. coli has the advantage of fast and industrial-scale expression of rhG-CSF and remains among the preferred methods for producing therapeutic proteins. Successful production of rhGCSF at different scales for non-therapeutic use has been also reported in the COS cell line, ${ }^{[7]}$ Pichia pastoris ${ }^{[8]}$ Saccharomyces cerevisiae, ${ }^{[9]}$ transgenic animals, ${ }^{[10]}$ or plant cultures. ${ }^{[11]}$

The aim of the present work was to improve the expression yield of rhG-CSF in E. coli for small batch production by developing a process that would be easily scalable for clinical rhG-CSF manufacture. We have applied a recently developed autoinduction method for the batch expression of rhG-CSF to study whether this new system would increase cell mass and target-protein yield compared to conventional $E$. coli cell culture and induction with isopropyl $\beta$-D-thiogalactopyranoside (IPTG). ${ }^{[12]}$ The second goal of this study was to compare the conformation, activity and stability of rhG-CSF produced in autoinduction medium to the commercially available filgrastim (TEVAgrastim ${ }^{\circledR}$, TEVA Pharma AG). 


\section{Experimental}

All chemicals were purchased from Applichem (Germany), unless otherwise indicated.

\section{Cloning}

cDNA of non-glycosylated mature 174 amino acid splice variant of human G-CSF (CSF3, Genbank accession NP_757373; aa31-aa204 of the isoform B precursor) was synthesized at GeneArt ${ }^{\circledR}$ Gene Synthesis (Life Technologies Corp.) into a pMA shuttle vector. The synthetic construct was designed with an additional $\mathrm{N}$ '-terminal methionine, with adaptation of codon usage for expression in pET23system (Merck4Biosciences) ${ }^{[12 b]}$ and with both 5' NdeI and a 3' XhoI restriction sites for further subcloning into the expression vector pET23a(+). pET $23 \mathrm{a}(+)$ carrying the cDNA for rhG-CSF was then used to transform BL21(DE3)pLysS E. Coli (Merck4Biosciences).

\section{Expression}

Transformed BL21(DE3)pLysS E. Coli cells were resuspended in $2 \times 5 \mathrm{ml}$ LuriaBertani (LB) medium (Difco Laboratories, USA) supplemented with $100 \mu \mathrm{g} / \mathrm{ml}$ ampicillin. The pre-cultures were incubated at $29^{\circ} \mathrm{C}, 200 \mathrm{rpm}$ till $\mathrm{OD}_{600}=0.8$. $1 \mathrm{~L}$ of selective autoinduction medium containing $10 \mathrm{~g}$ Tryptone (Difco Laboratories, USA), $5 \mathrm{~g}$ yeast extract (Difco Laboratories, USA), $137 \mathrm{mM} \mathrm{NaCl}, 0.5 \mathrm{M}\left(\mathrm{NH}_{4}\right)_{2} \mathrm{SO}_{4}, 1 \mathrm{M}$ $\mathrm{KH}_{2} \mathrm{PO}_{4}, 1 \mathrm{M} \mathrm{Na}_{2} \mathrm{HPO}_{4}, 25 \mathrm{~g}$ glycerol, $2.5 \mathrm{~g}$ D-glucose, $10 \mathrm{~g} \alpha$-lactose ${ }^{[12 \mathrm{a}]}$ was inoculated with the first rhG-CSF pre-culture at $29{ }^{\circ} \mathrm{C}, 170 \mathrm{rpm}$ for $24 \mathrm{~h}$. In parallel, $1 \mathrm{~L}$ of selective LB medium was inoculated with the second rhG-CSF pre-culture and left at $29{ }^{\circ} \mathrm{C}, 180 \mathrm{rpm}$ till $\mathrm{OD}_{600}=0.8$. Then, rhG-CSF expression was induced with 2 $\mathrm{M}$ IPTG for $16 \mathrm{~h}$ at $29^{\circ} \mathrm{C}, 170 \mathrm{rpm}$. Both cell cultures were centrifuged at $4{ }^{\circ} \mathrm{C}, 3500$ $\times \mathrm{g}$ for $20 \mathrm{~min}$ and cell pellets were stored at $-20{ }^{\circ} \mathrm{C}$.

\section{IB Isolation and Solubilization}

Cell pellets were resuspended in $30 \mathrm{ml}$ Lysis buffer (30 mM Tris pH 8.5, $1 \mathrm{mM}$ ethylene diamine tetra acetic acid (EDTA), 0.1\% Triton X-100) supplemented with benzonase nuclease $25 \mathrm{U} / \mathrm{ml}$ (Merck4Biosciences) and $1 \mathrm{mM}$ phenylmethylsulfonyl fluoride (PMSF). Cells were disrupted by three cycles of homogenization using a French press. Cell debris and IBs were sedimented by centrifugation at $4{ }^{\circ} \mathrm{C}, 7000 \times \mathrm{g}$ for $40 \mathrm{~min}$. The supernatant was discarded and the IBs were resuspended and washed in 30 $\mathrm{ml}$ Lysis buffer supplemented with $1 \mathrm{mM}$ PMSF for $30 \mathrm{~min}$ at $4{ }^{\circ} \mathrm{C}$. IBs were sedimented by centrifugation at $4{ }^{\circ} \mathrm{C}, 7000 \times \mathrm{g}$ for $20 \mathrm{~min}$. The supernatant was discarded and IBs were resuspended and washed in $30 \mathrm{ml}$ Lysis buffer supplemented with $0.2 \%$ deoxycholic acid for $30 \mathrm{~min}$ at $4{ }^{\circ} \mathrm{C}$. IBs were sedimented by centrifugation at $4{ }^{\circ} \mathrm{C}, 7000 \times \mathrm{g}$ for $20 \mathrm{~min}$. The supernatant was discarded and the IBs were resuspended and washed twice for $30 \mathrm{~min}$ in 30 $\mathrm{ml} 30 \mathrm{mM}$ Tris $\mathrm{pH} 8.5$ in endotoxin-free water. IBs free of cell debris, DNA/RNA and endotoxins were finally sedimented by centrifugation at $4{ }^{\circ} \mathrm{C}, 7000 \times \mathrm{g}$ for 20 min and solubilized in $10 \mathrm{ml} 30 \mathrm{mM}$ Tris $\mathrm{pH} 8.5,1 \mathrm{mM}$ EDTA, $8 \mathrm{M}$ urea and $0.1 \mathrm{M}$ 2-hydroxy-1-ethanethiol overnight at $4{ }^{\circ} \mathrm{C}$ under $50 \mathrm{rpm}$ agitation.

\section{rhG-CSF Refolding}

rhG-CSF extracted in $8 \mathrm{M}$ urea was refolded by stepwise dialysis against $2 \mathrm{M}$ urea buffer (30 mM Tris pH 8.5, $2 \mathrm{M}$ urea, $2.5 \mathrm{mM}$ reduced glutathione, $0.8 \mathrm{mM}$ oxidized glutathione) at $4{ }^{\circ} \mathrm{C}, 50 \mathrm{rpm}$ through a 6-8 kDa MWCO Spectra/Por ${ }^{\circledR}$ membrane (Spectrum Laboratories).

\section{Size Exclusion Chromatography (SEC) and Formulation}

After dialysis rhG-CSF was concentrated to $2 \mathrm{ml}$ with Corning Spin-X UF concentrator $5 \mathrm{kDa}$ MWCO (Corning Inc.) at $4{ }^{\circ} \mathrm{C}, 4000 \times \mathrm{g}$. The concentrated protein was then filtered and loaded onto a Superdex 75 column (GE Healthcare) equilibrated with $30 \mathrm{mM}$ Tris $\mathrm{pH} 8.5,2 \mathrm{M}$ urea buffer. The protein was eluted at room temperature at a flow-rate of $0.5 \mathrm{ml} /$ min using the ÅTA FPLC system (GE Healthcare). Pooled fractions containing refolded rhG-CSF were submitted to three cycles of sequential concentration $\left(4{ }^{\circ} \mathrm{C}\right.$, $10000 \times \mathrm{g})$ and dilution with formulation buffer $(10 \mathrm{mM}$ acetate buffer $\mathrm{pH} 4.2$, sorbitol $5 \% \mathrm{~m} / \mathrm{w}$, Tween $0.003 \% \mathrm{v} / \mathrm{v}$ ) through a $5 \mathrm{kDa}$ MWCO membrane.

\section{Bioactivity Studies on rhG-CSF Produced in Autoinduction Medium vs. TEVAgrastim ${ }^{\circledR}$}

\section{Proliferation Test}

Cells of the mouse myeloid line NFS60 (CLS, Germany) were cultured in suspension in RPMI 1640 GlutaMax $^{\circledR}$ (Life Technologies) supplemented with $10 \%$ fetal calf serum (Life Technologies), $1 \mathrm{mM}$ sodium pyruvate, $50 \mu \mathrm{g} / \mathrm{ml}$ streptomycin, $50 \mathrm{U} / \mathrm{ml}$ penicillin (Life technologies), $10 \mathrm{ng} / \mathrm{ml} \mathrm{IL-3} \mathrm{(Sigma-Aldrich)} \mathrm{and} \mathrm{main-}$ tained at $37{ }^{\circ} \mathrm{C} / 5 \% \mathrm{CO}_{2}$. The cells were allowed to reach an exponential growth phase with the density of $\approx 10^{6} / \mathrm{ml}$ and the media was exchanged to supplemented RPMI 1640 GlutaMax $^{\circledR}$ with no IL-3. Then the cells were transferred to a 96-well plate (20000 cells/well) and the test rhGCSF preparations were added to the wells; each concentration was tested on six wells.
After $48 \mathrm{~h}$ of incubation, $10 \mu \mathrm{l}$ of the WST1 reagent (Roche Applied Science) were added to each well and the incubation was continued for $3 \mathrm{~h}$. The color change reflecting the number of viable cells was detected at $450 \mathrm{~nm}$ vs. $690 \mathrm{~nm}$ on a BioTek ELISA reader (BioTek).

\section{Activation of the Jak/STAT-3 Signaling Pathway}

Mouse myeloid NFS-60 cells were cultured in supplemented RPMI 1640 GlutaMax $^{\circledR}$ with $10 \mathrm{ng} / \mathrm{ml}$ of test rhGCSF preparations and IL-3, respectively. Six million cells of each culture were then sedimented at $450 \times \mathrm{g}$ for $5 \mathrm{~min}$ at $4{ }^{\circ} \mathrm{C}$ and the supernatant was discarded. $100 \mu \mathrm{l}$ of cold RIPA buffer (Sigma-Aldrich) was added to the cell pellet, vortexed and incubated on ice for $10 \mathrm{~min}$. The cell lysate was centrifuged at $8000 \times \mathrm{g}$ at $4{ }^{\circ} \mathrm{C}$ and the supernatant was used for immunoblotting.

$50 \mu \mathrm{g}$ of total protein from the cell lysate was boiled at $95{ }^{\circ} \mathrm{C}$ for $5 \mathrm{~min}$ and separated on a $10 \%$ SDS gel for $45 \mathrm{~min} / 200$ $\mathrm{V}$. The $0.2 \mu \mathrm{m}$ pore nitrocellulose membrane (Sigma-Aldrich) and the extra thick blot paper (BioRad) were equilibrated in water and transfer buffer ( $25 \mathrm{mM}$ Tris, 0.2 M glycine, $10 \%$ methanol, $0.05 \%$ SDS), respectively, for $20 \mathrm{~min}$. The protein transfer was carried out at $18 \mathrm{~V}$, at room temperature for $90 \mathrm{~min}$ in a Trans-Blot Semi-Dry Transfer Cell (BioRad). The nitrocellulose membrane was blocked for $60 \mathrm{~min}$ in $20 \mathrm{mM}$ Tris, $137 \mathrm{mM} \mathrm{NaCl}, 5 \%$ skimmed milk and $0.05 \%$ Tween 20 . The primary antibody solution (1:20000 rabbit anti-phosphoTyr ${ }_{705}$-STAT-3 or 1:2000 rabbit anti STAT-3 (Merck-Millipore) in blocking buffer) was incubated overnight at $4{ }^{\circ} \mathrm{C}$. The secondary antibody solution (1:4000 goat anti-rabbit HRP-conjugated antibody (Merck-Millipore) in blocking buffer) was incubated $60 \mathrm{~min}$ at room temperature. Chemiluminescence Detection Kit (Applichem) and FUJI medical X-ray film (FUJIFILM Corp.) were used to reveal the western blot after $30 \mathrm{~s}$ of exposure.

\section{Physico-chemical Studies on rhG- CSF Produced in Autoinduction Medium vs. TEVAgrastim ${ }^{\circledR}$}

\section{Conformation-Sensitive SDS-PAGE}

$3 \mu \mathrm{g}$ of rhG-CSF samples and TEVAgrastim ${ }^{\circledR}$ were loaded on a SDS-free acrylamide gel. Electrophoresis was run for $2 \mathrm{~h}$ at room temperature at $125 \mathrm{~V}$ on a Mini-PROTEAN ${ }^{\circledR}$ electrophoresys system (BioRad Laboratories). A SilverQuest Silver Staining Kit (Life Technologies) was used for protein visualization.

\section{Circular Dichroism Spectra}

Circular dichroism (CD) spectra were recorded at $4{ }^{\circ} \mathrm{C}$ on a Jasco J-815 spec- 
trophotometer (Jasco Inc.) equipped with a water-cooled Peltier unit in $0.05 \mathrm{~cm}$ Hellma quartz cuvette model 110-QS. CD spectra measurements were taken for 0.15 $\mathrm{mg} / \mathrm{ml} \mathrm{rhG}-\mathrm{CSF}$ at a scan rate of $100 \mathrm{~nm} /$ min with a data pitch of $0.5 \mathrm{~nm}$ and a band width of $1 \mathrm{~nm}$. Each spectrum represents the mean of two scans from $250 \mathrm{~nm}$ to $200 \mathrm{~nm}$. Buffers were used as blanks and their spectrum was subtracted from the recorded spectra of the samples. The secondary structure content was estimated by deconvolution procedures using Spectra Manager (Jasco Inc.). The CD unit used is the mean molar ellipticity $(\theta)$ expressed in $\left(\mathrm{deg} . \mathrm{cm}^{2} \cdot \mathrm{dmol}^{-1}\right)$ where rhG-CSF and TEVAgrastim ${ }^{\circledR}$ contained 175 residues.

\section{Melting Temperature Studies}

To define the midpoint of thermal denaturation $\left(\mathrm{T}_{\mathrm{M}}\right)$ for rhG-CSF and for TEVAgrastim ${ }^{\circledR}$ spectra were collected at $220 \mathrm{~nm}$ within the temperature range of $4-90{ }^{\circ} \mathrm{C}$ on $\mathrm{J}-815$ spectrophotometer (Jasco Inc.) equipped with a water-cooled Peltier unit in $0.05 \mathrm{~cm}$ Hellma quartz cuvette model 110-QS. Data were collected from $0.15 \mathrm{mg} / \mathrm{ml} \mathrm{rhG-CSF}$ samples. The rate of heating was fixed at $1{ }^{\circ} \mathrm{C} / \mathrm{min}$ with data pitch of $1^{\circ} \mathrm{C}$ and a delay time of $1 \mathrm{sec}$. $\mathrm{T}_{\mathrm{M}}$ was calculated using Spectra Manager (Jasco Inc.).

\section{Turbidity Studies}

The turbidity of rhG-CSF and TEVAgrastim ${ }^{\circledR}$ was evaluated by measuring the absorbance of both formulations at $350 \mathrm{~nm}$ on a Cary 50 UV-Vis spectrophotometer (Varian Inc.) in triplicate.

\section{Fluorescence Studies}

The extrinsic fluorescence of rhG-CSF and TEVAgrastim ${ }^{\circledR}$ was measured with a Fluoromax-4 spectrofluorometer (Horiba Jobin Yvon Inc.) using $1 \mathrm{mM}$ Nile Red (Acros Organics). Both protein formulations were at a concentration of $0.15 \mathrm{mg} /$ $\mathrm{ml}$ in water. Fluorescence spectra were recorded at $25^{\circ} \mathrm{C}$ in a $1 \mathrm{~cm}$ pathlength quartz cuvette (Hellma). Settings for the measurements were: $\lambda_{\mathrm{ex}}=541 \mathrm{~nm}$, excitation slit 2 $\mathrm{nm}$ and emission slit $5 \mathrm{~nm}$, integration time $1 \mathrm{~s}$. Each measurement was performed in triplicate.

\section{Results}

Transformed E. coli BL21 (DE3)pLysS harboring pET23(a)-rhG-CSF were grown in $1 \mathrm{~L}$ shake flask batch cultures. The expression of the protein was conducted in parallel in LB medium with induction by IPTG as a standard procedure and in autoinduction medium as described by Studier. ${ }^{[12 a]}$ rhG-CSF produced by both methods was expressed in the form of IBs, which were

Table 1. Summary of the efficiency of rhG-CSF production and recovery after expression in $1 \mathrm{~L}$ LB upon IPTG induction vs. 1L autoinduction media

$\begin{array}{lcc}\text { Expression method } & 1 \% \text { glucose } / 2 \mathrm{M} \text { IPTG } / 48 \mathrm{~h} & \text { Autoinduction media } / 24 \mathrm{~h} \\ \text { Wet cell mass } & 2.6 \mathrm{~g} & 7.1 \mathrm{~g} \\ \text { IBs' mass } & 39.4 \mathrm{mg} & 185.7 \mathrm{mg} \\ \text { rhG-CSF recovered } & 37.6 \mathrm{mg} & 180.3 \mathrm{mg} \\ \text { from IBs } & 14.6 \mathrm{mg} & 75.7 \mathrm{mg} \\ \text { Refolded rhG-CSF } & 39 \% & 42 \% \\ \text { Efficiency of refolding } & \text { a } & \end{array}$

aThe efficiency of refolding is calculated as the ratio between the protein recovered from IBs and the amount of refolded protein.

then washed and solubilized as outlined in the Experimental section. Proteins from both expression media were then solubilized in $8 \mathrm{M}$ urea, refolded and purified by SEC under identical conditions. The expression in autoinduction media allowed over three-fold higher culture density and over five-fold higher protein mass recovery per $1 \mathrm{~L}$ of media (Table 1 ). The specific yield (rhG-CSF recovered from IBs per gram biomass) was improved by more than 1.7-fold.

Refolded and purified rhG-CSF from autoinduction media was formulated as TEVAgrastim $^{\circledR}$ and its conformation was compared to the marketed rhG-CSF from TEVA Pharma AG. CD spectra and conformational-sensitive SDS-PAGE indicated similar $\alpha$-helical content and conformation between the formulated rhG-CSF from autoinduction media and the marketed TEVAgrastim $^{\circledR}$ (Fig. 1).

The biological activity of rhG-CSF expressed in autoinduction media was assayed by two in vitro approaches. The first method measures the specific activity of the protein formulation through the proliferation of murine myeloid NFS-60 cells in presence of the studied and reference rhGCSF. The bioactivity of rhG-CSF $(0.85 \mathrm{ng} /$ $\mathrm{ml}$ i.e. $0.85 \times 10^{6} \mathrm{IU} / \mathrm{mg}$ ) expressed in autoinduction media was comparable to the activity of TEVAgrastim ${ }^{\circledR}(0.80 \mathrm{ng} / \mathrm{ml}$ i.e. $0.8 \times 10^{6} \mathrm{IU} / \mathrm{mg}$ ) (Fig. 2A). The second assay is based on the activation of the Jak/ STAT-3 pathway and the phosphorylation of STAT-3 in murine myeloid NFS-60 cells in presence of active rhG-CSF. STAT-3 phosphorylation was similar when NFS60 cells were cultured with rhG-CSF expressed in autoinduction media and with TEVAgrastim $^{\circledR}$ (Fig. 2B). The aggregation level of rhG-CSF expressed in autoinduction media was investigated at $25^{\circ} \mathrm{C}$ by absorbance at $350 \mathrm{~nm}$ and fluorescence spectroscopy, and compared to TEVAgrastim ${ }^{\circledR}$. The extrinsic fluorescence emission of rhG-CSF measured in presence of Nile Red was $5.7 \%$ lower than the extrinsic fluorescence emission of TEVAgrastim ${ }^{\circledR}$ (Fig. 3A). The turbidity of rhG-CSF expressed in autoinduction media remained comparable to the one of TEVAgrastim ${ }^{\circledR}$ (Fig.
3B). The stability of rhG-CSF expressed in autoinduction media $v s$. TEVAgrastim ${ }^{\circledR}$ was also mapped by circular dichroism under temperature stress. The thermal stability of both protein formulations was identical (Fig. 4).

\section{Discussion and Conclusions}

E. coli is the most widely used system for the production of recombinant human G-CSF at small and industrial scale ${ }^{[12 b]}$ because of its simple nutrient requirement,

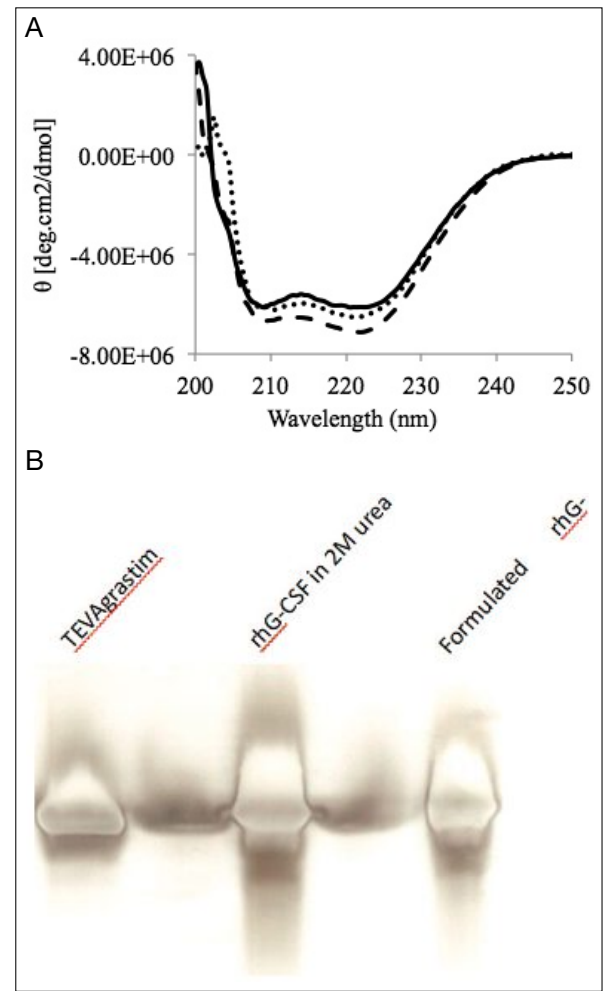

Fig. 1. Conformational analysis of refolded and formulated rhG-CSF after expression in autoinduction medium. A. CD spectrum of refolded rhG-CSF (dotted line), formulated rhG-CSF (full line) and TEVAgrastim ${ }^{\circledR}$ (dashed line) at $0.15 \mathrm{mg} / \mathrm{ml}$ in water. Data are plotted in terms of molar ellipticity [ $\theta]$. For each protein an average of two measurements is shown. $B$. Conformation-sensitive poly-acrylamide electrophoresis on $15 \%$ sodium dodecyl sulfatefree gel for formulated rhG-CSF expressed in autoinduction media and TEVAgrastim ${ }^{\circledR}$. Visualization was achieved by silver-staining. 


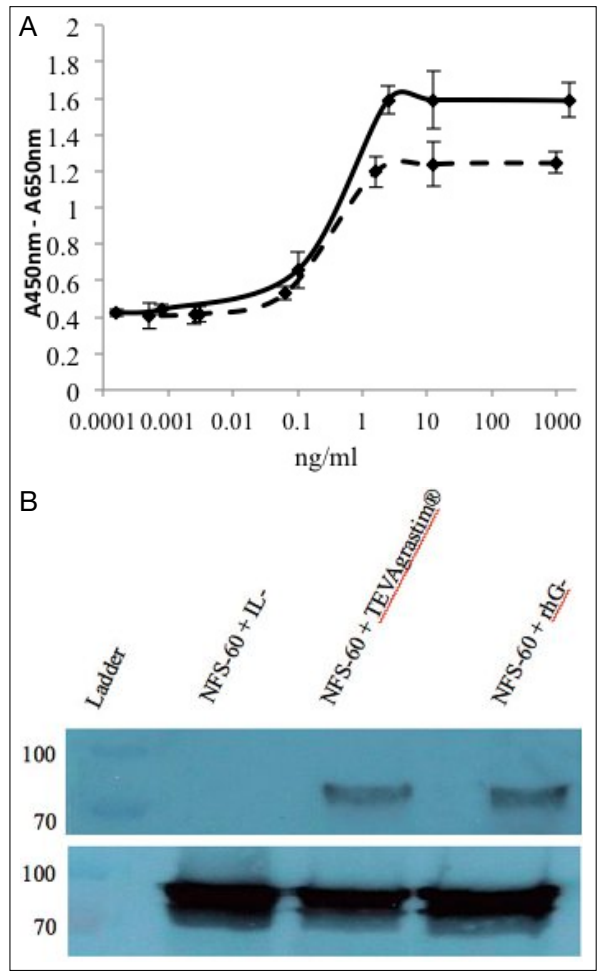

Fig. 2. Activity of rhG-CSF expressed in autoinduction medium. A. WST-1 cell proliferation assay on murine myeloid NFS-60 cells for formulated rhG-CSF and TEVAgrastim ${ }^{\circledR}$. B. STAT-3 phosphorylation by formulated rhGCSF and TEVAgrastim ${ }^{\circledR}$ detected by Western Blot with anti-phosphoTyr ${ }_{705}$-STAT-3 antibody (on the top). STAT-3 expression detected with anti-STAT-3 antibody (on the bottom). IL-3 was used as negative control for STAT-3 phosphorylation.

high growth rate and its well known molecular genetics and physiology.[13] Four main strategies may be adopted to enhance the recombinant protein production, namely, choice of culture medium, mode of cultivation, strain development and expression system control.[13] In this work we aimed at developing a simple, inexpensive and routine production of rhG-CSF at small, laboratory scale by flask batch culture and by the widely used $E$. coli BL21(DE3)pLysS strain and pET expression system for rhG-CSF expression.[6b,14] Thus, we have compared the use of two different expression system controls, a conventional IPTG induction system common for the recombinant protein expression in pET systems and a recently described autoinduction control, which has not been investigated yet for the up-stream processing of rhGCSF. [12a,15]

The autoinduction medium provides for 'autoinduction' of protein expression without the need to add inducers such as IPTG during mid-log phase of the cultures. The method is based on a buffered medium that contains a mixture of carbon sources, including lactose. Bacteria initially use glucose; when the glucose is
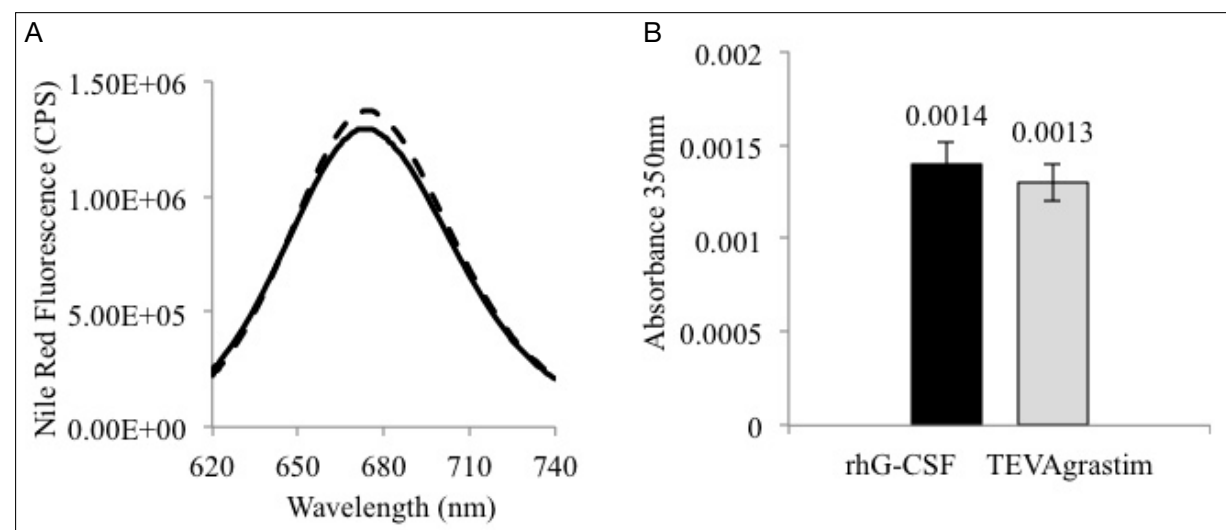

Fig. 3. Detection of protein aggregates in formulated rhG-CSF expressed in autoinduction medium. A. Comparison of fluorescence spectra of formulated rhG-CSF expressed in autoinduction medium (full line) and TEVAgrastim ${ }^{\circledR}$ (dashed line). Both proteins were measured at $25^{\circ} \mathrm{C}$ in water at a concentration of $0.15 \mathrm{mg} / \mathrm{ml}$. For each protein an average of three measurements is shown. The fluorescence emission spectrum was measured in presence of $1 \mathrm{mM}$ Nile Red. B. Turbidity (absorbance at $350 \mathrm{~nm}$ ) of rhG-CSF expressed in autoinduction medium and of TEVAgrastim ${ }^{\circledR}$ at $0.15 \mathrm{mg} / \mathrm{ml}$ in water.

exhausted, lactose can enter the cell and induce expression of the $\mathrm{T} 7$ polymerase from the DE3 lambda lysogen. The medium provides high culture densities and high yields of proteins, usually in inclusion bodies and may be used for the expression of recombinant proteins that are ultimately driven by the lac promoter such as recombinant proteins encoded into the pET expression system. The expression of rhG-CSF in autoinduction medium allowed over three-fold higher cell densities and over five-fold higher protein yield per $1 \mathrm{~L}$ of culture medium compared to expression under IPTG induction. Moreover, the

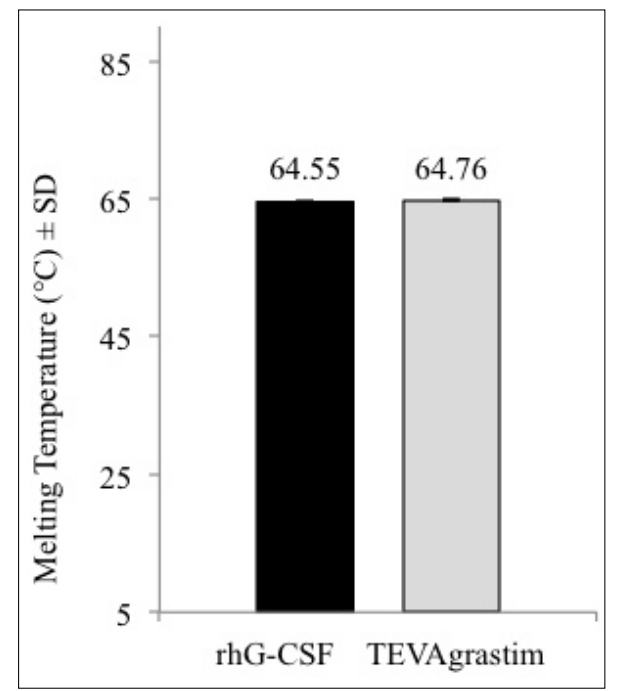

Fig. 4. Thermal stability of formulated rhG-CSF after expression in autoinduction medium and TEVAgrastim $^{\circledR}$. The midpoint of the thermal denaturation curve $\left(T_{M}\right)$ was defined for samples containing $0.15 \mathrm{mg} / \mathrm{ml}$ of protein in water with Jasco Manager (Jasco, Japan) on melting temperature curves registered at $220 \mathrm{~nm}$, within the temperature range of $5-90^{\circ} \mathrm{C}$. Standard deviations (SD) are shown as vertical bars and represent the average of two independent experiments. recombinant protein production was faster, due to the spontaneous induction by lactose, without monitoring cell density and without induction with IPTG. The overall costs of expression were also reduced by omitting the addition of IPTG.

The second goal of the present work was to compare the conformation, activity and physical stability of rhG-CSF expressed in autoinduction medium to the commercially available rhG-CSF, TEVAgrastim ${ }^{\circledR}$. rhG-CSF expressed in autoinduction medium demonstrated similar specific activity and Jak/STAT-3 activation as the control and thus remained in the range of $80-120 \%$ of the TEVAgrastim ${ }^{\circledR}$ activity, thus remaining in the biological experiment reproductivity range.

The comparable migration profile of the rhG-CSF formulation to the TEVAgrastim ${ }^{\circledR}$ control on a conformational-sensitive gel suggested that rhG-CSF expressed in autoinduction medium did not present oligomeric or aggregated forms neither partially unfolded nor modified conformations in comparison to the control. The $\alpha$-helical content $(47 \%)$ was slightly lower than the $\alpha$-helical content calculated for the control (50\%), but remained comparable to reported experimental values $(50 \% \alpha$-helices in rhG-CSF) ${ }^{[16]}$ and their variation might be due to the fact that complete spectra, including the far UV region from $200 \mathrm{~nm}$ to $180 \mathrm{~nm}$, could not be measured because of traces of formulation buffer within both samples.

The level of aggregation of the rhGCSF formulation was investigated by two complementary techniques. The UV absorbance at $350 \mathrm{~nm}$ was used to measure the turbidity of the pharmaceutical preparation and the extrinsic fluorescence in presence of Nile Red dye was employed to evaluate the presence of aggregates and/ or partial protein denaturation. ${ }^{[17]}$ In both 
assays rhG-CSF expressed in autoinduction medium showed similar levels of aggregation (turbidity) or even lower than TEVAgrastim $^{\circledR}$ (Nile Red Fluorescence). Moreover, the thermal unfolding temperature of formulated rhG-CSF obtained by autoinduction appeared to be similar to the one of TEVAgrastim ${ }^{\circledR}$.

In conclusion, various assays analyzing the conformation, activity and aggregate levels indicate that rhG-CSF from autoinduction medium has a similar profile to the marketed filgrastim (TEVA). rhG-CSF expression by autoinduction in $E$. coli is suggested as a simple, cost- and time-effective alternative to rhG-CSF production and can be further investigated for combination with various downstream rhG-CSF protocols ${ }^{[6 a, 6 c, 18]}$ and for an up-scaled hGCSF recombinant production.

\section{Acknowledgments}

We thank Prof. Leonardo Scapozza (University of Geneva) for providing the infrastructure for protein expression and purification. We are grateful to Pharmacie des Colombières, Versoix (Switzerland) for supplying the TEVAgrastim ${ }^{\circledR}$ used in this study. This work was in part supported by the UNIGAP fund of the University of Geneva.

Received: March 5, 2012

[1] a) E. Knudsen, P. O. Iversen, A. Boyum, T. Seierstad, G. Nicolaysen, H. B. Benestad, Eur.
J. Haematol. 2011, 87, 302; b) B. I. Lord, M. H. Bronchud, S. Owens, J. Chang, A. Howell, L. Souza, T. M. Dexter, Proc. Natl. Acad. Sci. USA 1989, 86, 9499; c) B. I. Lord, G. Molineux, Z. Pojda, L. M. Souza, J. J. Mermod, T. M. Dexter, Blood 1991, 77, 2154; d) N. A. Nicola, D. Metcalf, M. Matsumoto, G. R. Johnson, J. Biol. Chem. 1983, 258, 9017.

[2] a) G. D. Demetri, J. D. Griffin, Blood 1991, 78, 2791; b) V. Trillet-Lenoir, J. Green, C. Manegold, J. Von Pawel, U. Gatzemeier, B. Lebeau, A. Depierre, P. Johnson, G. Decoster, D. Tomita, C. Ewan, Eur. J. Cancer 1993, 29 A, $319 ;$ c) M. S. Aapro, J. Bohlius, D. A. Cameron, L. Dal Lago, J. P. Donnelly, N. Kearney, G. H. Lyman, R. Pettengell, V. C. Tjan-Heijnen, J. Walewski, D. C. Weber, C. Zielinski, Eur. J. Cancer 2011, in press.

[3] a) K. M. Rogers, Am. J. Med. Sci. 1992, 303, 429; b) G. Molineux, Curr. Pharm. Des. 2004, 10, 1235; c) G. M. Keating, Drugs 2011, 71 , 679; d) M. Hoglund, Med. Oncol. 1998, 15, 229 .

[4] a) M. Oh-eda, M. Hasegawa, K. Hattori, H. Kuboniwa, T. Kojima, T. Orita, K. Tomonou, T. Yamazaki, N. Ochi, J. Biol. Chem. 1990, 265, 11432; b) C. Nissen, Eur. J. Cancer 1994, 30A Suppl 3, S12; c) M. Ono, Eur. J. Cancer 1994, 30A Suppl 3, S7; d) C. Wang, M. Eufemi, C. Turano, A. Giartosio, Biochemistry 1996, 35, 7299; e) T. Arakawa, S. J. Prestrelski, L. O. Narhi, T. C. Boone, W. C. Kenney, J. Protein Chem. 1993, 12, 525 .

[5] a) J. J. Greene, Methods Mol. Biol. 2004, 267, 3; b) R. R. Burgess, Methods Enzymol. 2009, 463 , 259.

[6] a) C. Wang, L. Wang, X. Geng, Biomed. Chromatogr. 2007, 21, 1291; b) D. V. Rao, M. L. Narasu, A. K. Rao, Biotechnol. Appl. Biochem. 2008, 50, 77; c) C. Wang, L. Wang, X. Geng, Biotechnol. Prog. 2008, 24, 209; d)
R. Khalilzadeh, J. Mohammadian-Mosaabadi, A. Bahrami, A. Nazak-Tabbar, M. A. NasiriKhalili, A. Amouheidari, J. Ind. Microbiol. Biotechnol. 2008, 35, 1643; e) F. Wang, Y. Liu, G. Ma, Z. Su, Appl. Biochem. Biotechnol. 2009 , 159, 634; f) J. Chen, Y. Liu, X. Li, Y. Wang, H. Ding, G. Ma, Z. Su, Protein Expr. Purif. 2009. 66, 82

[7] S. Mizushima, S. Nagata, Nucleic Acids Res. 1990, 18, 5322 .

[8] M. A. Lasnik, V. G. Porekar, A. Stalc, Pflugers Arch. 2001, 442 (6 Suppl 1), R184.

[9] C. S. Bae, D. S. Yang, K. R. Chang, B. L. Seong, J. Lee, Biotechnol. Bioeng. 1998, 57, 600.

[10] R. Varki, E. Pequignot, M. C. Leavitt, A. Ferber, W. K. Kraft, BMC Clin. Pharmacol. 2009, 9, 2.

[11] S. Y. Hong, T. H. Kwon, Y. S. Jang, S. H. Kim, M. S. Yang, Protein Expr. Purif, 2006, 47, 68

[12] a) F. W. Studier, Protein Expr. Purif. 2005, 41 , 207; b) D. V. Krishna Rao, J. V. Rao, M. L. Narasu, A. K. Bhujanga Rao, Mol. Biotechnol. 2008, 38, 221; c) H. P. Sørensen, K. K. Mortensen, J. Biotechnol. 2005, 115, 113

[13] V. Babaeipour, M. P. Abbas, Z. Sahebnazar, R Alizadeh, Bioprocess. Biosyst. Eng. 2010, 33, 591.

[14] E. N. Lee, Y. M. Kim, H. J. Lee, S. W. Park, H. Y. Jung, J. M. Lee, Y. H. Ahn, J. Kim, Pharm. Res. 2005, 22, 1735.

[15] F. W. Studier, B. A. Moffatt, J. Mol. Biol. 1986, $189,113$.

[16] P. Wingfield, R. Benedict, G. Turcatti, B. Allet, J. J. Mermod, J. DeLamarter, M. G. Simona, K. Rose, Biochem. J. 1988, 256, 213.

[17] B. Demeule, R. Gurny, T. Arvinte, Int. J. Pharm. 2007, 329, 37.

[18] M. Zaveckas, B. Baskeviciute, V. Luksa, G Zvirblis, V. Chmieliauskaite, V. Bumelis, $\mathrm{H}$. Pesliakas, J. Chromatogr. A 2000, 904, 145. 